\title{
A Principal-Agent Explanation for Technology Transfer
}

\author{
Beryl Zi-Lin Kuo \\ Taipei College of Maritime Technology, New Taipei City, Taiwan
}

Chien-Hsin Lin

Da-Yeh University, Changhua, Taiwan

\begin{abstract}
Technology licensing and transfer is subject to problems of asymmetric information including moral hazard. This study explores the effects of informal governance, knowledge tacitness, and organizational receptivity on the preference of variable royalty scheme in the context of technologylicensing. Drawing on the classic principalagent model, we assume that the variable royalty scheme is a process-based contract where the licensee is the principal and the licensor is the agent. The results show that informal governance facilitating goal alignment is positively associated with the variable royalty scheme (i.e. the process-based contract). Organizational receptivity promotes the legitimacy to imposing routines, evaluating the technology, and forming expectation, and is positively associated with the variable royalty scheme. Knowledge tacitness is negatively associated with the variable royalty payment, which implies less transfer programmability moves payment from variable royalties to a fixed fee. Our arguments are significantly different from classic principal-agent relationship that does not involve the dimension of licensee transfer and monitoring capacity.
\end{abstract}

Keywords: International technology transfer, principal-agent relationship, organizational receptivity, knowledge tacitness

\section{INTRODUCTION}

7 he buyer-supplier relationship studies in the principal-agent model assume that (1) the principal and the agent sign a compensation contract; (2) the agent chooses an action, but the principal cannot observe this choice; (3) the action determines the agent's output; and (4) the agent receives the compensation specified by the contract (Gibsons, 2005; Obloj and Zemsky, 2015). The technology licensing and transfer is one scenario of the buyer-supplier relationship. Technology licensing refers to the transfer of the right of using proprietary product, production, or managerial technologies by collecting a fixed fee (abbreviated as a fee) or variable royalties (abbreviated as royalties) in return from the licensor to the licensee (Contractor, 1981). The licensee is the technology buyer and the licensor is the technology supplier. Technology transfer, the most crucial part in the form of technology licensing contract transfer, relates to the process that the licensor assists the licensee in incorporating the technology with recipient operations (Rogers, 2002). In other words, the licensor transfer the technological knowledge to the licensee and
Journal of Technology Management for Growing Economies

Vol. 6, No. 2

October 2015 pp. $26-44$

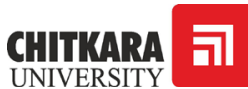

C 2015 by Chitkara University. All Rights Reserved. 
pay a fee or royalties to the licensor. In other words, the licensor is the agent who receives the compensation specified by the contract and determines the quality of technology transfer (Gibsons, 2005; Obloj and Zemsky, 2015; Sharma, 1997).

Technological knowledge transfer is to problems of asymmetric information including moral hazard (Poblete and Spulber, 2014). Prior literature points out that the efficiency and information asymmetry are main reasons for choosing between a fee and royalties. The studies on the efficiency put more emphasis on a fee because it avoids the difficulty of output verification and the non-contractual uses of technology. Royalties increase the marginal cost to the licensee using the new technology and consequently decrease the total amount that the licensee is willing to pay (Kamien and Tauman, 1986). Information asymmetry is also important because royalties are offered to signal a high value for the technology (Gallini and Wright, 1990) and to induce the licensor's involvement (Aulakh, Cavusgil, and Sarkar, 1998). However, the considerations of efficiency and information asymmetry do not guarantee the transfer smoothly and successfully because technology transfer is costly.

The licensor-licensee link can be viewed as an principal-agent relationship as the licensee attempts to gain accurate technological information and desired benefits from technology licensors (Bergen et al., 1992; Bessy and Brousseau, 1998; Obloj and Zemsky, 2015). If (1) the relationship is supported by transaction or relationship specific investments, (2) the licensee's knowledge frequently becomes obsolete due to rapid change, and/or (3) as the licensor's technology of the interest makes the relationship irreplaceable or replace at a cost for the licensee, the licensor may be tempted to seek self-interest in the forms of moral hazard, adverse selection, and/or imperfect commitment (Obloj and Zemsky, 2015; Ouchi, 1979; Sharma, 1997). Since moral hazard is fully recognized as an important obstacle for licensing through arm's length contract, the contractual focus becomes should the payment be on the basis of a fee, royalties, or a hybrid (Contractor, 1981).

In this study, we attempt to document the payment scheme of technology transfer through licensing in principal-agent relationship. The next section presents the theoretical background of principal-agent model and plural governance in the context of technology transfer through licensing, and the hypothesis. The subsequent section presents the research methods, followed by the empirical findings. The final sections discuss the results and their implications.
A principal-agent explanation 
Kuo, B. Z. Lin, C.

\section{THEORY AND HYPOTHESIS}

\section{Royalties Imply a Process-based Contract in Principal-agent Relationship}

The focus of principal-agent model is to choose the efficient agency cost given to the human and information assumptions (Eisenhardt, 1989). A process based contract is more efficient when the cost of information is less than the cost of transfer risk. Conversely, an outcome-based contract is more efficient when the cost of information is lower. The principal offers an outcome-based contract when the agent payment is evaluated on the basis of actual outcomes that relate to reliance on objective measures and relatively little managerial involvement. On the contrary, the principal may offer a process-based contract when the principal directly evaluates that whether the agent's actual activities comply with the pre-specified processes. Assumption underlying a processbased contract is avoidance of moral hazard arising from both the hidden action and information (Arrow, 1985; Bergen et al., 1992).

The above elaboration is from the principal perspective assuming that the principal knows how the agent does a job and so drives the exchange, but the principal does not know what the agent does. However, Sharma (1997) points out the assumption behind that the principal knows how to do is problematic. The task per se matters. When the principal seeks out the agent for his expert knowledge, and when there are the professional agent and the lay principal, or when the principal is the first time to delegate technology development, it is likely that the principal cannot specify the task goals or cannot design the appropriate contract, since expert power asymmetry favors the agent (Sharma, 1997).

Under a fee, the licensee pays the licensor an upfront fee (initial payment) at the onset of the contract, followed by the technology transfer, and then final payments. The licensor prefers to a fee because he may reduce the possible damage once the licensee terminates the contracts after access to the disclosed information and proceeds on his own. The benefit of a fee is avoiding the difficulty of verifying the licensee's output and the non-contractual uses of the technology (Kamien and Tauman, 1986). However, the licensee bears the performance risk, once no final product can be produced and sold. Therefore, the exchange risk perceived by the licensee is the greatest among all payment structures.

Royalties do not specify total price that makes payments a function of the value, generated by the successful commercialization of the transferred technology. Once no final product is produced and sold, the licensor cannot get any return from his effort, thus spreading the risk between two parties and mitigating moral hazard (Cebrián, 2009). It co-aligns the risk of the licensee

Journal of Technology Management for Growing Economies, Volume 6, Number 2, October 2015 
with the revenue of the licensor, but both parties have to afford subsequently monitor, communication, and enforcement costs at maintaining a continuous contract is invested (Aulakh et al., 1998).

Recalled from the previous discussion, technology transfer through licensing for a technology learner involves managerial involvement in transfer activities and resource committed in monitoring how transfer is performed in the local context. Compared to an outcome-based contract, a processbased contract entails greater supervision and tends to have a longer time perspective (Eisenhardt, 1989). To thoroughly learn the knowledge of the interest, a process-based contract requires the licensee to invest greater time and effort in monitoring how technology transfer is performed. Alternatively, royalties signal the value of the technology that the licensor sacrifices the short-term return in exchange for the long-term profit and then minimizes the exchange risks perceived by the licensee (Gallini and Wright, 1990; Helm and Kloyer, 2004). Hence, royalties implies a process-based contract in this study. An exception is that a process-based contract shifts the payment risks to the licensee but royalties spread the risk between the licensor and the licensee.

\section{Informal Governance}

Informal governance corresponds to prior link and relational satisfaction that makes inter-organizational relationships which become more embedded into economic and social context over time and is idiosyncratic to the exchange relationships (Dekker, 2004). Firms with exchange relationships are adept to manage the contracting relationships in that contractual refinement promotes more cooperative and long-term exchange relationship. When the technology of interest involves with the private information held more by the licensor, the licensor and licensee, in response to keep-on-with-it define remedies for foreseeable contingencies or specify processes for resolving unforeseeable outcomes (Poppo and Zenger, 2002). Recall from the previous discussion that royalties involve periodic written reports, prompt written notice of any departures from the contract, examining and auditing all relevant records in relation to transferred knowledge. Accordingly, we predict the relationship between informal governance and royalty payments is positive.

Hypothesis 1: Informal governance is positively associated with the more proportional use of royalties.

\section{Knowledge Tacitness}

Knowledge tacitness is context-specific that the licensor is not fully aware of the details of the performance and finds it difficult or impossible to articulate a full account of the details (Nelson and Winter, 1982). Moreover, the licensee,

Journal of Technology Management for Growing Economies, Volume 6, Number 2, October 2015
A principal-agent explanation 
Kuo, B. Z. Lin, C. whether articulated or not, may not know how to use the articulated knowledge. The transfer of tacit technology is more difficult to accomplish than the transfer of articulated knowledge under the circumstances of interorganizational technology transfer (Kogut and Zander, 1993). The more tacit the technology is, the more stock of technological knowledge the licensor is and the more expertise asymmetry exists between the two parties. The licensee offers royalties to ask for the thorough transfer. Accordingly, we hypothesize that:

Hypothesis 2: Knowledge tacitness is positively associated with the more proportional use of royalties.

\section{Organizational Receptivity}

In this study, organizational receptivity corresponds to the assertiveness of its learning intent and capacity. Hamel (1991) defines organizational receptivity as a partner's learning capacity or absorptiveness. Larsson, Bengtsson, Henriksson, and Sparks (1998) modify Hamel's definition and redefine it as the intent and capacity to absorb the disclosed knowledge. We follow Larsson et al.'s (1998) definition in this research and propose that a highly receptive learning licensee enacts internal routines or organizational processes to solve informational asymmetry and risk-bearing problems and to enhance a firm's technological competitiveness.

Intelligence gathering signals the licensee's intent to learn codified knowledge. When the licensee embeds the identification and assimilation of codified knowledge in operational routines, its receptivity to technological learning is proactive. Proactively searching patent data and scientific literature to identify the state of the external art provides the licensee with architectural knowledge, which enables him to directly assess the characteristics of technological technology, and then the information asymmetry ex ante is reduced. After assimilating the gathered intelligence, the expertise enables the licensee to earn the legitimacy to design meaningful monitoring systems and/ or set up relevant measurement standards to assess the transfer process, and reduces the need of investment in excessive information systems to monitor the licensor's transfer activities. Accordingly, we hypothesize that:

Hypothesis 3a: Intelligence gathering is positively associated with the more proportional use of royalties.

Transferring in knowledge does not automatically lead to acquisition of technological capability. Articulated technical data cannot capture all of the knowledge necessary to practice the technology. Much of the knowledge possessed by the licensor may be experiential. The licensee must invest its own time and effort in experimentation to learn how to practice a transferred

Journal of Technology Management for Growing Economies, Volume 6, Number 2, October 2015 
technology. Stated differently, the licensee has to develop adequate internal technological capability because greater internal capability is typically associated with greater ability to take advantage of external technology (Veugelears and Cassiman, 1999). The accumulated, path-dependent, and internal capability contributes to the development of absorptive capacity (Cohen and Levinthal, 1990). If the licensee fails to learn from the licensor with sufficient absorptive capacity, the application of the new technology with royalties is unsatisfactory to both parties. On the other hand, the licensee's absorptive capacity enables him to learn by interaction and then reduces the need to employ excessive monitoring mechanism to ensure contract effectiveness. Hence,

Hypothesis 3b: Absorptive capacity is positively associated with the more proportional use of royalties.

When there is substantial market overlap or product similarity, the licensee has more prior knowledge base to absorb the technological knowledge. The knowledge base promotes the likelihood of the commercialization of the knowledge. However, the licensor has temptations for not actually transferring all the promised know-how and marketing support necessary for the licensee to effectively integrate the technology into its operations, because it is costly and risky (Arora, 1995), once the price is paid. Under royalties, complementarily marketing knowledge of the licensee may tempt the licensor restraining from his shirking and transferring all the knowledge that facilitates the monetary return of the technology. Moreover, royalties signal the licensee not imitating or competing in similar product/geographic markets (Gallini and Wright, 1990). Therefore, under royalties firms operate in similar markets and supply chains may scrutinize with more confidence in their partner's opportunistic behavior (Kim, 2009). Accordingly, we hypothesize that:

Hypothesis 3c: Knowledge proximity is positively associated with the more proportional use of royalties.

\section{METHODS}

\section{Data}

The empirical study employed a questionnaire approach designed to collect data for testing the validity of the model and research hypotheses. Six hundred questionnaires were mailed to collected name-pools of Taiwanese manufacturing sectors that have in-house R\&D staffs. The unit of analysis is the contract. If there was more than one technology transfer project for the subject company, the company was asked to choose the most significant
A principal-agent explanation 
Kuo, B. Z. Lin, C. one. Two weeks after the initial mailing, a follow-up mailing was sent out with a duplicate copy of the questionnaire and a return envelope. Of the 133 questionnaires returned, seven responses reported that they did not have any technology transfer case and twenty-two were incomplete. 104 usable questionnaires were received, resulting in an effective response rate of $21 \%$.

\section{Measures}

Most measures for key constructs were derived from existing studies in the literature and adapted them to the context of the present study. This study used a fee versus royalties in accordance with the existing literature (e.g. Bousquet et al., 1998). Because a mixture of the two schemes is common and most contracts are not clustered into dichotomous categories (Bessy and Brousseau, 1998), the measurement of the payment scheme adopted is dispersed along a simplified continuum ranging from primarily a fee to primarily royalties, on a five-point scale that asks about the frequency (Bousquet et al., 1998).

Most independent variables were measured with multiple items using fivepoint Likert scales ranging from $1=$ strongly disagree to $5=$ strongly agree. Table 1 summarizes the measurement items. Licensee reputation and relational satisfaction are operationalized as informal governance. The value of licensee reputation and relationship satisfaction is maximized through an ongoing relationship, rather than discrete transaction. Licensee reputation is a two-item scale measuring the licensee's goodwill and the quality of fulfilling contracts (Das and Teng, 2001). Relational satisfaction is a two-item scale signifying the extent of cooperation satisfaction experienced by the licensee (Dyer, 1997). Knowledge tacitness is assessed using a three-item scale that measures the extent of the relative difficulty of transferring and imitating the technology (Kogut and Zander, 1993). Intelligence gathering is a four-item scale indicating the extent that the recipient's intelligent asset management facilitates transfer and learning (Winter, 2004). Absorptive capacity is a five-item scale signifying the recipient's ability to value, assimilate, and commercially exploit its transferred knowledge (Cohen and Levinthal, 1990). Knowledge proximity is a three-item scale indicating the extent of market overlap or product similarity between a licensee and its licensor (Vishwasrao, 2007).

This study includes six control variables. Source specificity is measured on a two-item scale signifying the extent to which alternative technology is available to the licensee (Heide and John, 1988). Technological and marketing dependence presents the licensee dependence where greater dependence on the licensor's support signals the licensee in need of the licensor's future support and enables the licensee to commit more resources in calling for the support. Technological dependence including three items represents the

Journal of Technology Management for Growing Economies, Volume 6, Number 2, October 2015 
licensee's assessment of the extent of dependence on the licensor for critical components, technically engineering and manufacturing service support. Marketing dependence is a three-item scale measuring the extent of marketing and after-sales support (Provan and Skinner, 1989).

Japan source is measured with a dichotomous item, with 1 indicating technology from Japan, otherwise 0. Among all technological superior countries, Japan has a historically close tie with Taiwan as there existed fiftyyear colonial relationship between these two countries. Hence, Japanese licensors may keep long-term business relationships with Taiwanese licensee, expecting royalties. Licensee size is a two-item scale composed by the logarithm of annual sales and the logarithm of capital. Large firms are more risk neutral than small firms and have more cash resources and bargaining power to pay a fee (Cebrián, 2009; Vishwasrao, 2007). Contractual scope is a three-item scale measuring the exclusivity of licensing, the extent of technical training and support, and the scope of licensing (Cho, 1988). The scope and nature of licensing contracts influences the choice between a fee and royalties. Technology licensing comprises the legal use of technology and assistance in technological and management support (Contractor, 1981); hence, agreementspecific factors influence the payment scheme in technology licensing (Cho, 1988). The broader contractual scope is expectedly negative with royalties (Helm and Kloyer, 2004).

Table 1: Measurement Properties

\begin{tabular}{|l|c|c|}
\hline \multicolumn{1}{|c|}{ Constructs and items } & $\begin{array}{c}\text { Factor } \\
\text { loadings }\end{array}$ & $\begin{array}{c}\text { Composite } \\
\text { reliability }\end{array}$ \\
\hline Licensee reputation & & $\mathbf{0 . 9 0}$ \\
\hline The extent of licensee goodwill & 0.93 & \\
\hline The extent of performing contracts & 0.88 & $\mathbf{0 . 9 0}$ \\
\hline Relational satisfaction & & \\
\hline $\begin{array}{l}\text { The extent of fulfilling obligations among prior } \\
\text { collaborations }\end{array}$ & 0.93 & \\
\hline $\begin{array}{l}\text { The extent of satisfaction among prior collabo- } \\
\text { rations }\end{array}$ & 0.88 & $\mathbf{0 . 7 6}$ \\
\hline Knowledge tacitness & 0.90 & \\
\hline $\begin{array}{l}\text { Use of transferred knowledge needs to intgrate } \\
\text { multiple knowledge }\end{array}$ & 0.60 & \\
\hline $\begin{array}{l}\text { Specificity of critical material, parts/ compo- } \\
\text { nents, or production process }\end{array}$ & & \\
\hline The extent of at-site coaching from the source & 0.63 & \\
\hline
\end{tabular}

Journal of Technology Management for Growing Economies, Volume 6, Number 2, October 2015
A principal-agent explanation 
Kuo, B. Z.

Lin, C.

\begin{tabular}{|l|c|c|}
\hline \multicolumn{1}{|c|}{ Constructs and items } & $\begin{array}{c}\text { Factor } \\
\text { loadings }\end{array}$ & $\begin{array}{c}\text { Composite } \\
\text { reliability }\end{array}$ \\
\hline Intelligence gathering & & $\mathbf{0 . 8 4}$ \\
\hline $\begin{array}{l}\text { The extent of providing patented information to } \\
\text { relevant functional departments }\end{array}$ & 0.54 & \\
\hline The extent of patent search before R\&D & 0.89 & \\
\hline $\begin{array}{l}\text { The extent of understanding patent filing status of } \\
\text { related technologies }\end{array}$ & 0.98 & \\
\hline $\begin{array}{l}\text { The extent of the training of intellectual property } \\
\text { rights }\end{array}$ & 0.53 & \\
\hline Absorptive capacity & & $\mathbf{0 . 8 7}$ \\
\hline $\begin{array}{l}\text { The ability to understand and analyze new } \\
\text { knowledge }\end{array}$ & 0.81 & \\
\hline The ability to modify or transform new knowledge & 0.83 & \\
\hline $\begin{array}{l}\text { The ability to apply new knowledge to improve } \\
\text { production efficiency }\end{array}$ & 0.72 & \\
\hline $\begin{array}{l}\text { The ability to apply new knowledge to develop } \\
\text { new product }\end{array}$ & 0.68 & \\
\hline $\begin{array}{l}\text { The ability to apply new knowledge to improve } \\
\text { quality }\end{array}$ & 0.74 & \\
\hline Knowledge proximity & & $\mathbf{0 . 8 2}$ \\
\hline $\begin{array}{l}\text { The similarity of existing product lines between } \\
\text { two parties }\end{array}$ & 0.88 & \\
\hline $\begin{array}{l}\text { The overlap of existing markets between two } \\
\text { parties }\end{array}$ & 0.76 & \\
\hline $\begin{array}{l}\text { The similarity of newly-developed products } \\
\text { through application of the acquired technology } \\
\text { between two parties }\end{array}$ & 0.67 & \\
\hline Source specificity & 0.77 & \\
\hline $\begin{array}{l}\text { The availability of alternative source of technolo- } \\
\text { gy after contracting }\end{array}$ & 0.94 & \\
\hline $\begin{array}{l}\text { The availability of alternative source of technolo- } \\
\text { gy before contracting }\end{array}$ & 0.69 & \\
\hline Technological dependence & & \\
\hline $\begin{array}{l}\text { Critical technology of product design depends on } \\
\text { sourcing }\end{array}$ & \begin{tabular}{l} 
\\
\hline $\begin{array}{l}\text { Critical material or parts/ components depend on } \\
\text { sourcing }\end{array}$
\end{tabular} \\
\hline
\end{tabular}

Journal of Technology Management for Growing Economies, Volume 6, Number 2, October 2015 


\begin{tabular}{|l|c|c|}
\hline \multicolumn{1}{|c|}{ Constructs and items } & $\begin{array}{c}\text { Factor } \\
\text { loadings }\end{array}$ & $\begin{array}{c}\text { Composite } \\
\text { reliability }\end{array}$ \\
\hline Production efficiency depends on sourcing & 0.89 & \\
\hline Marketing dependence & & $\mathbf{0 . 9 4}$ \\
\hline Market information depends on sourcing & 0.88 & \\
\hline Marketing skills depend on sourcing & 0.96 & \\
\hline After-sales service depends on sourcing & 0.89 & \\
\hline Licensee size & & $\mathbf{0 . 9 5}$ \\
\hline Log (Capital) & 0.97 & \\
\hline Log (Sales) & 0.94 & \\
\hline Contractual scope & & $\mathbf{0 . 8 0}$ \\
\hline The extent of exclusivity of licensing & 0.78 & \\
\hline The extent of technical and training support & 0.69 & \\
\hline The scope of technology licensing & 0.78 & \\
\hline
\end{tabular}

A principal-agent explanation

Note: All factor loadings are significant at $p<0.01$ based on bootstrapped standard errors.

Because bias in self-reported survey data is a potential threat to validity, some tests were conducted to check the validity of the survey data. Due to the single informant in each questionnaire, the study employed Harman's one factor model to examine the potential common method bias. The principal component analysis generates 12 factors with Kaiser criteria (eigenvalues $>1$ ) that account for $73 \%$ of the total variance. Since a single factor does not emerge, common method variance is not a significant problem in the data (Podsakoff and Organ, 1986). Second, we examine two kinds of response bias in the data as suggested by Amstron and Overton (1977). The comparison of first-stage versus second-stage respondents in terms of capital and established year is employed to examine the early versus late responding bias. The comparison of firms that respond to this survey versus those do not but listed at the collected namepools in terms of the self-reported capital with the MOEA's Commerce Industrial Services database is also employed to examine the responding versus non-responding bias. There is no statistically significant difference emerges from two student tests. The absence of differences can be consistent with the claim that response bias seems not to be a potential problem (Amstron and Overton, 1977).

\section{DATA AND ANALYSIS}

Partial least square (PLS), a structural equation modeling technique employing a principal component analysis (Chin, 1998), was used to examine the reliability and construct validity of all measures. As seen in Table 1, the results 
Kuo, B. Z. Lin, C. show that the composite reliabilities (Fornell and Larcker, 1981) of all measures are high and exceed the recommended threshold of 0.70 , ranging between 0.76 (Knowledge tacitness) and 0.94 (Marketing dependence). The results suggest the measures provide internal consistency of scales. Second, convergent validity is assessed by the magnitude of the factor loading of each manifest indicator on its proposed construct. The average factor loading of Table 1 is 0.79 , and all loadings are highly significant (all p's $<.01$ ), showing that all indictors are effectively measuring their proposed constructs. Third, discriminant validity is evaluated by an average variance extracted (AVE) test (Fornell and Larcker, 1981). To support the discriminant validity of a construct, the AVE measure should be greater than the variance shared between the construct and other constructs in the model (i.e. the squared correlation between two constructs). As shown in Table 2, each AVE measure on the diagonal is greater than the offdiagonal elements in the corresponding rows and columns, thus confirming the discriminant validity. Overall, the constructs demonstrate adequate measurement properties.

Table 2: AVE Test of Discriminant Validity

\begin{tabular}{|l|l|c|c|c|c|c|c|c|c|c|c|c|}
\hline & & 1 & 2 & 3 & 4 & 5 & 6 & 7 & 8 & 9 & 10 & 11 \\
\hline 1. & Licensee reputation & $\mathbf{0 . 8 2}$ & & & & & & & & & & \\
\hline 2. & $\begin{array}{l}\text { Relational } \\
\text { satisfaction }\end{array}$ & 0.06 & $\mathbf{0 . 9 9}$ & & & & & & & & & \\
\hline 3. & $\begin{array}{l}\text { Knowledge } \\
\text { tacitness }\end{array}$ & 0.00 & 0.00 & $\mathbf{0 . 5 2}$ & & & & & & & & \\
\hline 4. & $\begin{array}{l}\text { Intelligence } \\
\text { gathering }\end{array}$ & 0.09 & 0.00 & 0.02 & $\mathbf{0 . 5 8}$ & & & & & & & \\
\hline 5. & Absorptive capacity & 0.19 & 0.00 & 0.05 & 0.20 & $\mathbf{0 . 5 8}$ & & & & & & \\
\hline 6. & $\begin{array}{l}\text { Knowledge } \\
\text { proximity }\end{array}$ & 0.07 & 0.08 & 0.00 & 0.00 & 0.00 & $\mathbf{0 . 6 0}$ & & & & & \\
\hline 7. & Source specificity & 0.00 & 0.02 & 0.00 & 0.00 & 0.02 & 0.00 & $\mathbf{0 . 7 4}$ & & & & \\
\hline 8. & $\begin{array}{l}\text { Technological } \\
\text { dependence }\end{array}$ & 0.00 & 0.03 & 0.00 & 0.03 & 0.00 & 0.08 & 0.00 & $\mathbf{0 . 5 4}$ & & & \\
\hline 9. & $\begin{array}{l}\text { Marketing } \\
\text { dependence }\end{array}$ & 0.00 & 0.00 & 0.04 & 0.02 & 0.00 & 0.03 & 0.04 & 0.12 & $\mathbf{0 . 8 4}$ & & $\mathbf{0 . 5 7}$ \\
\hline 10. & Licensee size & 0.13 & 0.08 & 0.00 & 0.08 & 0.03 & 0.00 & 0.03 & 0.03 & 0.00 & $\mathbf{0 . 9 1}$ & \\
\hline 11. & Contractual scope & 0.03 & 0.04 & 0.00 & 0.00 & 0.07 & 0.04 & 0.00 & 0.02 & 0.01 & 0.01 \\
\hline
\end{tabular}

Note: Bold numbers along the diagonal show the AVE. Numbers below the diagonal represent the squared correlations.

Journal of Technology Management for Growing Economies, Volume 6, Number 2, October 2015 
Table 3 provides Pearson zero-order correlation matrix for all related variables. The highest correlation coefficient is between recipient intelligence gathering and learning capability ( $\mathrm{r}=0.44)$ indicating that there are no strongly correlated variables. The positive correlation between royalty scheme and licensee reputation, relational satisfaction, intelligence gathering, absorptive capacity, and knowledge proximity are consistent with our hypothesis. The negative correlation between the royalties scheme and knowledge tacitness is contradictory to our expectation. Except contractual scope, the correlations between the royalexplanation ties scheme with the other five control variables are positive. This suggests that exclusivity of licensing, greater support and service, and greater scope of licensing is negatively correlated with the royalties scheme; the greater the source specificity, technological and marketing dependence, Japan source, and recipient size, the higher the likelihood of more proportional royalties is, respectively.

Table 3. Zero-order Correlation Matrix

\begin{tabular}{|c|c|c|c|c|c|c|c|c|c|c|c|c|c|c|c|}
\hline & & M & SD & 1 & 2 & 3 & 4 & 5 & 6 & 7 & 8 & 9 & 10 & 11 & 12 \\
\hline 1 & $\begin{array}{l}\text { Royalties } \\
\text { scheme }\end{array}$ & 2.94 & 1.41 & & & & & & & & & & & & \\
\hline 2 & $\begin{array}{l}\text { Recipient } \\
\text { reputation }\end{array}$ & 4.12 & 0.62 & 0.29 & & & & & & & & & & & \\
\hline 3 & $\begin{array}{l}\text { Relational } \\
\text { satisfaction }\end{array}$ & 1.69 & 0.99 & 0.19 & 0.20 & & & & & & & & & & \\
\hline 4 & $\begin{array}{l}\text { Knowledge } \\
\text { tacitness }\end{array}$ & 3.13 & 0.75 & -0.22 & 0.05 & 0.09 & & & & & & & & & \\
\hline 5 & $\begin{array}{l}\text { Intelligence } \\
\text { gathering }\end{array}$ & 2.91 & 0.84 & 0.08 & 0.31 & -0.01 & 0.21 & & & & & & & & \\
\hline 6 & $\begin{array}{l}\text { Absorptive } \\
\text { capacity }\end{array}$ & 3.75 & 0.55 & 0.20 & 0.34 & 0.03 & 0.24 & 0.44 & & & & & & & \\
\hline 7 & $\begin{array}{l}\text { Knowledge } \\
\text { proximity }\end{array}$ & 3.12 & 0.91 & 0.26 & 0.28 & 0.28 & 0.00 & 0.04 & 0.01 & & & & & & \\
\hline 8 & $\begin{array}{l}\text { Japan } \\
\text { source }\end{array}$ & 0.30 & 0.46 & 0.25 & 0.22 & 0.33 & -0.07 & 0.09 & 0.03 & 0.35 & & & & & \\
\hline 9 & $\begin{array}{l}\text { Source } \\
\text { specificity }\end{array}$ & 2.62 & 0.90 & 0.14 & -0.02 & 0.13 & -0.07 & 0.04 & -0.18 & -0.07 & 0.03 & & & & \\
\hline 10 & $\begin{array}{l}\text { Technolog- } \\
\text { ical depen- } \\
\text { dence }\end{array}$ & 3.17 & 0.79 & 0.31 & -0.04 & 0.13 & 0.07 & -0.08 & 0.07 & 0.21 & 0.08 & 0.04 & & & \\
\hline 11 & $\begin{array}{l}\text { Marketing } \\
\text { dependence }\end{array}$ & 2.28 & 0.94 & 0.21 & & -0.06 & -0.17 & -0.20 & 0.01 & 0.17 & 0.25 & -0.22 & 0.28 & & \\
\hline 12 & $\begin{array}{l}\text { Licensee } \\
\text { size }\end{array}$ & 3.04 & 0.90 & 0.15 & 0.32 & 0.27 & 0.03 & 0.40 & 0.18 & 0.06 & -0.02 & 0.15 & 0.12 & -0.03 & \\
\hline 13 & $\begin{array}{l}\text { Contractual } \\
\text { scope }\end{array}$ & 3.56 & 0.78 & -0.08 & 0.11 & 0.22 & -0.01 & -0.07 & 0.23 & 0.22 & 0.16 & -0.05 & 0.15 & 0.10 & 0.11 \\
\hline
\end{tabular}

Note: Significant if $\mid$ correlation $\mid 0.20(p<0.05)$ 
Kuo, B. Z. Lin, C.

The study tested the hypothesis simultaneously using PLS, which has been widely applied in strategic management research (Hulland, 1999). PLS with bootstrap estimates of standard errors was used due to the characteristics of our sample size and the non-normal distribution of the data. The models with 1000 bootstrapping runs demonstrate good explanatory power, because the R_squared values for the constructs are ranging from 0.24 to 0.44 .

Licensee reputation and relational satisfaction as proxy of informal governance have significantly positive effects on the royalty scheme. The results suggest the higher the recipient reputation is and the greater satisfaction is, the more likely the royalties scheme is to be adopted, supporting Hypothesis 1. This finding is consistent to the classic agency theory that goal congruency is positively associated with a process-based contract (Eisenhardt, 1989).

Hypothesis 2 predicted knowledge tacitness that requires the licensor to interact closely and requires longer time to transfer knowledge would lead to the greater likelihood of a royalty scheme. Knowledge tacitness in the model has a negative effect on the royalty scheme, which is consistent with Bessy, Brousseau and Saussier (2008). Hypothesis 2 is not supported. One of the rationales maybe the incompetent licensee is vulnerable to contracting. Knowledge tacitness increases the expected transfer costs (Kogut and Zander, 1993). If the licensee opts for a royalty scheme, the licensor's return for the technology will be reduced in addition to transfer costs. It is also less likely that the licensor provides more constructive suggestions to the licensee beyond the contract as transfer costs increase. The other reason is lack of technical expertise makes the licensee difficult to invest a commodity-type information system or to choose between the costs of outcome measurement and process observation (Sharma, 1997). Therefore, knowledge tacitness increases knowledge asymmetry and decreases the licensor's willingness to collaborate. Hence, a fees scheme is preferred.

Hypothesis 3 predicted that the likelihood of using more proportional royalties would be greater when the licensee has greater organizational receptivity. Intelligence gathering has a positive effect on the royalty scheme but is insignificant, not supporting Hypothesis 3a. The rationale behind this insignificance may be the major objective that catching-up firms in NIEs use intelligence gathering activities for infringement avoidance more rather than to acquire codified knowledge. Absorptive capacity and knowledge proximity have significantly positive effects on the royalty scheme, supporting Hypotheses $3 \mathrm{~b}$ and $3 \mathrm{c}$.

All the control variables except licensee size have effects on the royalty scheme. The effects of source specificity, technological and marketing dependence on the royalty scheme are significantly positive. Japan source has a significantly positive effect on the royalty scheme. When the technology is from Japan, the 
royalty scheme is more likely. It is possible that because Japanese and Taiwanese are long-term oriented, royalties imply continuing business relationships.

Table 4: Regression Model

\begin{tabular}{|l|r|r|r|r|r|l|}
\hline & \multicolumn{3}{|c|}{ Model 1 } & \multicolumn{3}{c|}{ Model 2 } \\
\hline Licensee reputation & & & & 0.11 & $(2.449)$ & $*$ \\
\hline Relational satisfaction & & & & 0.09 & $(1.979)$ & $*$ \\
\hline Knowledge tacitness & & & & -0.28 & $(8.266)$ & $* *$ \\
\hline Intelligence gathering & & & & 0.10 & $(1.803)$ & \\
\hline Absorptive capacity & & & & 0.28 & $(6.253)$ & $* *$ \\
\hline Knowledge proximity & & & & 0.15 & $(3.871)$ & $* *$ \\
\hline Source specificity & 0.16 & $(3.776)$ & $* *$ & 0.19 & $(4.658)$ & $* *$ \\
\hline Technological dependence & 0.28 & $(5.880)$ & $* *$ & 0.27 & $(6.590)$ & $* *$ \\
\hline Marketing dependence & 0.17 & $(3.431)$ & $* *$ & 0.12 & $(3.326)$ & $* *$ \\
\hline Japan source & 0.22 & $(5.352)$ & $* *$ & 0.12 & $(2.701)$ & $* *$ \\
\hline Licensee size & 0.05 & $(1.252)$ & & -0.07 & $(1.805)$ & \\
\hline Contractual scope & -0.16 & $(2.972)$ & $* *$ & -0.26 & $(4.852)$ & $* *$ \\
\hline $\mathbf{R}^{2}$ & 0.24 & & & 0.44 & & \\
\hline
\end{tabular}

Licensee size in this study is used as an aggregate indicator of sales and assets to test the effect of the licensee firm size. The effect of licensee size on the royalty scheme is insignificant in this study. This finding is inconsistent with the literature. Measured as the logarithm of capital of the Spanish recipient's firm size, Cebrián (2009) demonstrates the larger the licensee is, the greater the likelihood it is to choose a fee relative to royalties. Using 765 Indian technology licenses, Vishwasrao (2007) finds that licensing contracts are more likely to use royalties when the licensee sale is relatively high, and less likely to use royalties when the licensee asset is relatively high.

Contractual scope has significantly negative effects on the royalty scheme. The negative effect of contractual scope suggests that the greater exclusivity of licensing, extent of technical training and support, and scope of licensing are, the less likely the royalties scheme is, and the greater the likelihood of fee scheme is.

\section{DISCUSSION AND IMPLICATIONS}

Whereas many multinational enterprises capitalize on licensing out to extract the residual value of proprietary assets and to expand abroad with relatively
A principal-agent explanation 
Kuo, B. Z. Lin, C. few resources, more and more firms license in to supplement firms' internal innovation processes and gain access to firm-specific resources (Tsai and Wang 2009). The logic following the classic agency theory neglects the licensee learning motives and capacity. We contribute to the literature on contracting for technological knowledge transfer by explicitly examining the effects of informal governance, knowledge tacitness, and organizational receptivity on the payment scheme. This study examines the effects of informal governance, knowledge tacitness, and organizational receptivity on the payment scheme in the international technology licensing context. We proposed a simplified continuum of payment scheme, which then forms the basis for an empirical analysis of choice of payment scheme. The empirical results are from a survey of 104 technology licenses in Taiwan.

From a theoretical perspective, the results extend existing principal-agent model. Firstly, the technology licensor-licensee link fits the principal-agent relationship. The technology licensee is considered as the principal who has a need of developing new technology but lacks of relevant resources to complete the task. The technology licensor is considered to be the agent who is hired to conduct technology development for the licensee. The licensor is mostly superior to the licensee in terms of either time lead in technology life cycle or in technological capabilities. Hence, the principal-agent relationships under the circumstances of international technology licensing are different from the power structure of the classic principal-agent model.

Secondly, royalties approximate a process-based contract in this study because both are long-term oriented and require more managerial involvement. A process-based contract promotes the licensee /principal to engage in active involvement by committing more resources in collecting information. When the licensee/principal needs to employ the licensing to learn the externally new technology, he will make more relationship-specific investment in activating the learning and winning the licensor/agent's support. Royalties enable the licensor/agent to make relationship-specific investment in return for successful commercialization of technology in the local context.

Thirdly, according to the classic principal-agent model, the completion risk of a process-based contract is borne by the principal. But in licensing practices, royalties split the application risk between the licensor and licensee. One critical issue in designing the agency contract arises that is how the licensee/principal reduces the risk perceived by the licensor/agent. We then apply Sharma's (1997) argument to reduce the licensee/principal's perceived risk. The choice of payment scheme results from the difference in risk preferences of the licensee/principal and licensor/agent. As a complement to the contract, informal governance enables to define remedies for foreseeable

Journal of Technology Management for Growing Economies, Volume 6, Number 2, October 2015 
contingencies or to specify processes for resolving unforeseeable events in licensing. Knowledge tacitness reduces the effectiveness of technology transfer, but organizational receptivity promotes the legitimacy to impose routines and decision rights and consequently enhances the licensee transfer and monitoring capacity. Our arguments are significantly different from classic principal-agent relationship that does not involve the dimension of licensee transfer and monitoring capacity.

Finally, organizational receptivity consisting of intelligence gathering, knowledge proximity, and absorptive capacity is the motivation and capacity of organizational learning that a firm accumulates his technological capability. Organizational receptivity is not only helpful for knowledge transfer but good to the principal-agent relationship. The elements pave the way not only for building architecture knowledge for assessing the technological knowledge of interest, but establishing information system to monitor how the transfer proceeds and to reduce the ambiguity of the technology transformation. Royalties become more feasible to the licensor as organizational receptivity increases and the application risk perceived reduces.

\section{Limitations and Outlook}

This study has several limitations that should be addressed in future endeavors. Firstly, it investigates only a simplified payment scheme i.e. a fee, royalties, and a combination of these two, leaving other schemes unexplored. The determinants of payment scheme may differ depending on which licensing exists, such as cross-licensing, OEM/ODM, machinery/equipment procurement, joint ventures, ex post renegotiation, etc. Future research should examine various types of licensing along with the payment modes, as the factors associated with governance and capability may differ. New strategies and issues in moral hazard and power structure complicate the relationships, and more frameworks must be developed to study these emergent licensing settings.

Secondly, we conjecture royalties approximate with a process-based contract whereby a fee versus royalty scheme and a process-based versus an outcome-based scheme disperse a continuum, respectively. We do not empirically test the relationship between these two types of contract: royalties versus process-based. As some studies operationalize a process-based and outcome-based scheme as distinct constructs (e.g. Gencturk and Aulakh, 1995), further studies may examine the approximation.

Thirdly, technology licensing, especially patent licensing, comprises the proactive and reflective licensing. This study takes the proactive licensing into consideration because the reflective licensing as a kind of inward licensing for
A principal-agent explanation 
Kuo, B. Z. Lin, C. not infringement involves more legal issue than internalization or substitution issue.

Finally, the data is a small Taiwan's ICT firms, which cannot generalize to other sectors in NIEs, but it suggests a reasonable starting point. Future research may extend similar inquiries to other national settings, incorporate industry-level parameters, and employ dyad analyses on before-contracting and after-contracting.

\section{REFERENCES}

Armstron, S. and Overton, T. (1977) 'Estimating Non-Response Bias in Mail Surveys', Journal of Marketing Research, 14:3, pp. 396-402.

Arora, A. (1995) 'Licensing Tacit Knowledge: Intellectual Property Rights and the Market for Know-how', Economics of Innovation and New Technology, 4:1, pp. 41-59. http://dx.doi. org/10.1080/10438599500000013.

Arrow, K. J. (1985) 'The Economics of Agency', in Pratt, J. \& R. Zeckhauser (Eds.), Principals and Agents: The Structure of Business, Boston: Harvard Business School Press, pp.37-51.

Aulakh, P. S., Cavusgil, S. T., and Sarkar, M. B. (1998) 'Compensation in International Licensing Agreements,' Journal of International business Studies, 29:2, pp. 409-420.

Bergen, M., Dutta, S., and Walker, O. C. Jr. (1992) 'Agency Relationships in marketing: a Review of the Implications and Applications of Agency and Related Theories,' Journal of Marketing, 56, pp. 1-24.

Bessy, C, Brousseau, E., and Saussier, S. (2008) 'Payment Schemes in Technology Licensing Agreements: a Transactional Cost Approach. Working paper, Forum, Université Paris X and ATOM, Université Paris 1 (Cited on 12 Jan, 2011). Available from $<$ brousseau.info/ pdf/CBEBSSPayLic0801.pdf>.

Bessy, C. and Brousseau, E. (1998) 'Technology Licensing Contracts Features and Diversity', International Review of Law and Economics, 18:4, pp. 451-489. http://dx.doi.org/10.1016/ S0144-8188(98)00018-0.

Bousquet, A., Cremer, H., Ivaldi, M., and Wolkowicz, M. (1998) 'Risk Sharing in Licensing', International Journal of Industrial Organization, 16:5, pp. 535-554.

Cebrián, M. (2009) 'The Structure of Payments as a Way to Alleviate Contractual Hazards in International Technology Licensing', Industrial and Corporate Change, 18:6, pp. 11351160. http://dx.doi.org/10.1093/icc/dtp016.

Chin, W. W. (1998) 'The Partial Least Squares Approach for Structural Equation Modeling', in Marcoulides, G.A. (Ed.), Modern Methods for Business Research, NJ: Lawrence Erlbaum Associates, pp. 295-336.

Cho, K. R. (1988) 'Issues of Compensation in International Technology Licensing', Management International Review, 28:2, pp. 70-79.

Cohen, W. M. and Levinthal, D. A. (1990) 'Absorptive Capability: a New Perspective on Learning and Innovation', Administrative Science Quarterly, 35:1, pp. 128-152.

Contractor, F. (1981), International Technology Licensing. D. C. Lexington, MA: Heath and Company.

Das, T. K. and Teng, B-S. (2001) 'Trust, Control and Risk in Strategic Alliances: an Integrated Framework', Organization Studies, 22:2, pp. 251-283.

Dekker, H. C. (2004) 'Control of Inter-organizational Relationships: Evidence on Appropriation Concerns and Coordination Requirements', Accounting, Organizations and Society, 29, pp. 27-49.

Dyer, J. H. (1997) 'Effective Interfirm Collaboration: How Firms Minimize Transaction Costs and Maximize Transaction Value', Strategic Management Journal, 18:7, pp. 535-556.

Eisenhardt, K. M. (1989) 'Agency Theory: an Assessment and Review', Academy of Manage-

Journal of Technology Management for Growing Economies, Volume 6, Number 2, October 2015 
ment Review, 14:1, pp. 57-74.

Fornell, C. and Larcker, D. F. (1981) 'Evaluating Structural Equation Models with Unobservable Variables and Measurement Error', Journal of Marketing Research, 18:1, 39-50.

Gallini, N. T. and Wright, B. D. (1990), 'Technology Transfer under Asymmetric Information', Rand Journal of Economics, 21:1, pp. 147-160.

Gencturk, G. and Aulakh, P. S. (1995) 'The Use of Process and Output Controls in Foreign Markets', Journal of International Business Studies, 26:4, pp. 755-786.

Gibsons, R. (2005) 'Incentives Between Firms (and Within)', Management Science, 51:1, pp. 2-17.

Hamel, G. (1991) 'Competition for Competence and Inter-partner Learning within International Strategic Alliances', Strategic Management Journal, 12(Special Issue 1), 83-103. http:// dx.doi.org/10.1002/smj.4250120908.

Heide, J. B. and John, G. (1988) 'The Role of Dependence Balancing in Safeguarding Transaction-Specific Assets in Conventional Channels', Journal of Marketing, 52:1, pp. 20-35.

Helm, R. and Kloyer, M. (2004) 'Controlling Contractual Exchange Risks in R\&D Interfirm Cooperation: an Empirical Study', Research Policy, 33, pp. 1103-1122.

Hulland, J. (1999) 'Use of Partial Least Square (PLS) in Strategic Management Research: a Review of Four Recent Studies', Strategic Management Journal, 20:2, 195-204. http:// dx.doi.org/10.1002/(SICI)1097-0266(199902)20:2<195::AID-SMJ13>3.0.CO;2-7.

Kamien, M .I. and Tauman, Y. (1986) 'Fees versus Royalties and the Private Value of a Patent', Quarterly Journal of Economics, 101, pp. 471-491.

Kim, Y. J. (2009) 'Choosing between International Technology Licensing Partners: an Empirical Analysis of U.S. Biotechnology Firms', Journal of Engineering and Technology Management, 26:1-2, pp. 57-72.

Kogut, B. and Zander, U. (1993) 'Knowledge of the Firm and the Evolutionary Theory of Multinational Cooperation', Journal of International Business Studies, 24:4, pp. 625-645.

Larsson, R. Bengtsson, L., Henriksson, K., and Sparks J. (1998)' The Interorganizational Learning Dilemma: Collective Knowledge Development in Strategic Alliances,' Organization Science, 9:3, pp. 285-305.

Nelson, R. and Winter, S. G. (1982), An Evolutionary Theory of Economic Change, Cambridge MA: Harvard University Press.

Obloj, T. and Zemsky, P. (2015), Value Creation and Value Capture under Moral Hazard: Exploring the Micro-Foundations of Buyer-Supplier Relationships', Strategic Management Journal, 36:8, pp. 1146-1163. http://dx.doi.org/10.1002/smj.2271.

Ouchi, W. G. (1979) 'A Conceptual Framework for the Design of Organizational Control Mechanisms', Management Science, 25:9, pp. 833-848.

Podsakoff, P. and Organ, D. (1986) 'Self-Reports in Organizational Research: Problems and Prospects', Journal of Management, 12:4, pp. 531-544.

Poblete, J. and Spulbery, D. (2014) 'Managing Invention and Innovation: from Delegated R\&D to Implementation', (cited on 20 Aug, 2015). Available from http://www.law.northwestern.edu/research-faculty/searlecenter/workingpapers/documents/Poblete_Spulber_Managing_Innovation July 2014.pdf.

Poppo, L. and Zenger, T. (2002) 'Do Formal Contracts and Relational Governance Function as Substitutes or Complements?' Strategic Management Journal, 23:8, pp. 707-725. http:// dx.doi.org/10.1002/smj.249.

Provan, K. G. and Skinner, S. J. (1989) 'Interorganizational Dependence and Control as Predictors of Opportunism in Dealer-Supplier Relations', Academy of Management Journal, 32:1, pp. 202-212.

Rogers, E.M. (2002) 'The Nature of Technology Transfer', Science Communication, 23:3, pp. 323-341. http://dx.doi.org/10.1177/107554700202300307.

Sharma, A. (1997) 'Professional as Agent: Knowledge Asymmetry in Agency Exchange', Academy of Management Review, 22:3, pp. 758-798.
A principal-agent explanation 
Kuo, B. Z.

Lin, C.
Tsai, K-H. and Wang, J-C. (2009) 'External Technology Sourcing and Innovation Performance in LMT Sectors: an Analysis Based on the Taiwanese Technological Innovation Survey', Research Policy, 38:3, pp. 518-526.

Veugelers, R. and Cassiman, B. (1999) 'Make and Buy in Innovation Strategies: Evidence from Belgian Manufacturing Firms', Research Policy, 28:1, pp. 63-80.

Vishwasrao, S. (2007) 'Royalties vs. Fees: How Do Firms Pay for Foreign Technology,' International Journal of Industrial Organization, 25:4, pp. 741-759.

Winter, S. G. (2004) 'Knowledge and Competence as Strategic Assets', in Handbook on Knowledge Management 1, Volume 1 of the series International Handbooks on Information Systems, pp. 129-152.

Dr. Beryl Zi-lin Kuo, Assistant Professor, Taipei College of Maritime Technology, Taiwan. Email: berylkuo@mail.tcmt.edu.tw.

Dr. Chien-Hsin Lin, Associate Professor, Da-Yeh University, Taiwan.

Email: 1in@mail.dyu.edu.tw 